\title{
96 穴ケモタキシスチャンバーを用いた白血球走化性試験
}

\author{
—マイクロプレートリーダーによる走化性の定量的評侕一
}

\section{塚本芳雄・福谷幸子・大浦＼cjkstart清*}

\begin{abstract}
Monocyte chemotaxis by the 96 well assembly-One step quantitative measurement by the micro-plate reader

A new multi-well assembly was used for the in vitro chemotaxis assay of human peripheral blood monocytes. N-formylmethionyl-leucyl-phenylalanine caused concentration-dependent migration of the monocyte into the lower surface of the metal flamed membrane fllter. Measurement was performed by the microplate reader $(550 \sim 600 \mathrm{~nm})$, and the absorbance showed the complete dependence on the number of migrated cells.

Yoshio Tsukamoto - Sachiko Fukutani - Kiyoshi Ohura* key words : monocytes, chemotaxis, in vitro, multi-well assembly, absorbance
\end{abstract}

白血球は, 炎症巣で貪食・殺菌などの機能を発 揮したり免疫反応に携わることにより生体防御の 役割を果たすが，白血球が炎症巣に出現するため には, 活性化された補体や生体内に侵入した細菌 に由来する因子によって誘起される白血球の遊走 (走化性)が生じなければならない.

in vitro で白血球の走化性（ケモタキシス）を試 験する方法としては, スライドグラスとカバーグ ラスの間隙で細胞の動きを観察する方法 ${ }^{11}$, 毛細 管を利用する方法 ${ }^{22}$, アガロースプレート法3), メンブランフィルター法4) などがある。1962年に Boyden ${ }^{4)}$ がボイデンチャンバーを用いて白血球の 走化性を簡単に定量的に測定することができるメ ンブランフィルター法を報告し，さらに1980年に 48 穴のケモタキシスチャンバー5,6) が開発された ことにより, 試験に要する操作時間が飛躍的に短 縮された。

しかし走化性を定量的に評価するためには，一 定の培養時間内に走化性因子に向かって遊走した 細胞の数を光学顕微鏡で肉眼的に計測するか 7 ( $^{78}$, または，接眼レンズに接続したビデオカメラでと らえた顕微鏡像をイメージアナライザーで分析し

* Department of Pharmacology, Osaka Dental University, 5-31, Otemae 1-chome, Chuo-ku, Osaka 540 , Japan 大阪歯科大学薬理学講座
たのちに細胞数を計測しなければならない 5,6$).$ いずれにしてもメンブランフィルター上のいくつ かの細胞遊走面ごとに，位置をわずかずつ移動さ せたり焦点を合わせるなどの顕微鏡操作が必要で あることにはかわりがなく，走化性試験自体の操 作が簡単になり所要時間が短縮されたにもかかわ らず, 結果を定量的に測定する過程では煩雑な作 業を必要とした。

本研究では最近開発された96穴ケモタキシスチ ヤンバーを用いてヒト白血球の走化性試験を行っ たところ, 少量の白血球で安定した実験結果が得 られ, さらに走化性の評価はマイクロプレートリ ーダーで吸光度を読み取ることによってきわめて 短時間内に完了し，正確な定量データが得られた ので報告する.

\section{材料と方法}

（1） ヒト単球の分離

実験に用いた単球は，健康なとトの末梢血から Böyum の報告 ${ }^{9)}$ に準じた方法で分離した。血液は heparin (20 units/nıl, Nobo) で処理した注射器 で各実験ごとに正中皮静脈から採取し，0.02 M phosphate buffered saline (pH 7.2, PBS) で約 3 倍に希釈したのち, Ficoll-Paque (Pharmacia)上 に重層し, 室温 $\left(20^{\circ} \mathrm{C}\right)$ で $400 \times \mathrm{g} 35$ 分間の遠心 を行った。単球は血漿と Ficoll-Paque の境界部 から採取し，Turk 染色液(ナカライテスク)に浮 遊させて血球数計算盤で細胞数を算定した。

（2）細胞浮遊液の調整

単球は，塚本(1981) ${ }^{10)}$ の報告に基づき，ウシ血 清アルブミン(2\%, Sigma)と HEPES $(20 \mathrm{mM}$, ナカライテスク)を含む $\mathrm{pH} 7.0$ の Gey's balanced salt solution (Gey's BSA)を用いて，細胞密度が 1，2，3，4，拈よび $5 \times 10^{6}$ 個 $/ \mathrm{ml}$ となるように それぞれ調整した。

（3）走化性因子の調整

走化性試験の陽性 対照としては, N-formyl- 


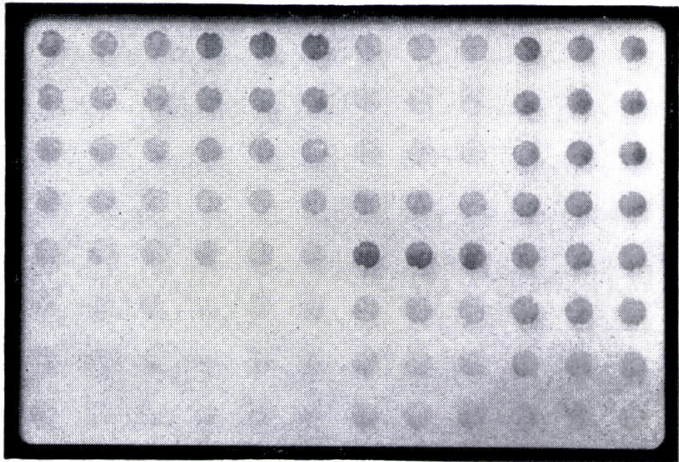

図 1 Flamed membrane filter of the 96 well chemotaxis chamber

methionyl-leucyl-phenylalanine (FMLP, Sigma)を 用いた。 FMLPは, Gey's BSA と Veronal buffer (145 mM NaCl, $1.82 \mathrm{mM} \quad \mathrm{Na}-5,5$-diethylbarbiturate, $312 \mathrm{mM} \mathrm{5,5-diethylbarbituric} \mathrm{acid,} 0.5$ $\left.\mathrm{mM} \mathrm{MgCl}_{2}, 0.15 \mathrm{mM} \mathrm{CaCl} 2, \mathrm{pH} 7.0\right)$ とをそれ ぞれ $7: 5$ の割合で混和した溶液( $\operatorname{mix}$ sol)を用い て $10^{-11} \mathrm{M}$ から $10^{-6} \mathrm{M}$ の濃度範囲となるよらに 希釈した。

\section{（4）走化性試験}

走化性試験は 96 穴ケモタキシスチャンバー (Neuro Probe, Model AB 96)を用いて以下の方 法で行った。走化性因子溶液和よび陰性対照( mix sol)をそれぞれ $25 \mu 1$ ずつ bottom plate の lower well に満たし，あらかじめガスケットとメンブラ ンフィルター(孔径: $5 \mu \mathrm{m}$ ) を装着した top plate を bottom plate のら儎せて両 plateをネジ で固定した。つぎに細胞浮遊液を $40 \mu \mathrm{l}$ ずつ upper well に充填したのち, $37^{\circ} \mathrm{C}$ 飽和水蒸気の条件下 て90分間培養した。

培養終了後にチャンバーから取り外したフィル ターは, $37^{\circ} \mathrm{C}$ に温めた PBS で非付着細胞を洗 い落としたのち，フィルタ一表面に付着している 遊走細胞をDiff-Quik 染色液(国際試薬)で固定, 染色した。なお，染色後に綿棒または scraper 劣 用いてフィルターの非遊走面を清拭することによ

り，非遊走細胞を除去した。

\section{（5）走化性の評価}

メンブランフィルター(図 1 ) は, 室温で風乾し たのら, マイクロプレートリーダー (Bio-Rad, Model 2550 EIA reader, 波長 450〜 700 nm) 用 いて吸光度を測定した。実験はすべて triplicate

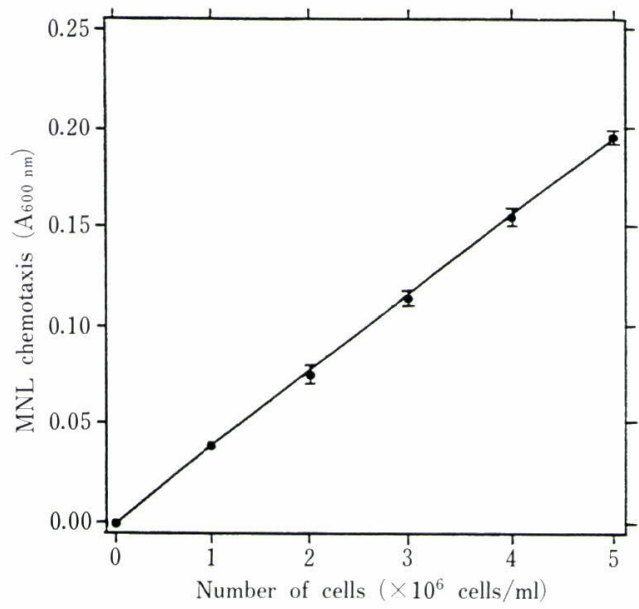

図 2 Cell dose dependent monocyte chemotaxis to FMLP

Data represents the mean $\pm \mathrm{SE}$ of triplicate filters (A $600 \mathrm{~nm}$, buffer control: 0.052 \pm 0.003 ).

で行らことにより吸光度の平均值と標準䛊差を求 めるとともに，3回以上繰り返して実験を行いデ ータの再現性を確認した。

\section{結 果}

（1）細胞密度の影響

FMLP $\left(10^{-8} \mathrm{M}\right)$ を走化性因子として $1 \times 10^{6}$ 個/ $\mathrm{ml}$ から $5 \times 10^{6}$ 個 $/ \mathrm{ml}$ の細胞密度に調整した細胞 浮遊液を用いて走化性試験を行い，波長 $600 \mathrm{~nm}$ での吸光度を測定したところ, 吸光度は細胞密度 に比例して直線的に上昇した(図 2 ).

（2）走化性因子の濃度の影響

$10^{-11} \mathrm{M}$ から $10^{-6} \mathrm{M}$ の濃度範囲の FMLP を走 化性因子として $5 \times 10^{6}$ 個 $/ \mathrm{ml}$ の細胞密度に調整 した細胞浮遊液を用いて走化性試験を行い，波長 $600 \mathrm{~nm}$ での吸光度を測定したところ，10-10 M 濃度以上の FMLP に対して走化性が認められ, $10^{-8} \mathrm{M}$ をピークとする用量反応曲線が得られた (困 3 ).

\section{（3）測定波長による影響}

FMLP $\left(10^{-8} \mathrm{M}\right)$ を走化性因子として $5 \times 10^{6}$ 個/ $\mathrm{ml}$ の細胞密度に調整した細胞浮遊液を用いて走 化性試験を行い，波長 450，492，550，600，打 よび $700 \mathrm{~nm}$ での吸光度をそれぞれ 測定したとこ 万, 吸光度は波長 $550 \mathrm{~nm}$ と $600 \mathrm{~nm}$ でもっとも 高い値を示す緩やかな曲線を描いた(表 1 )。 


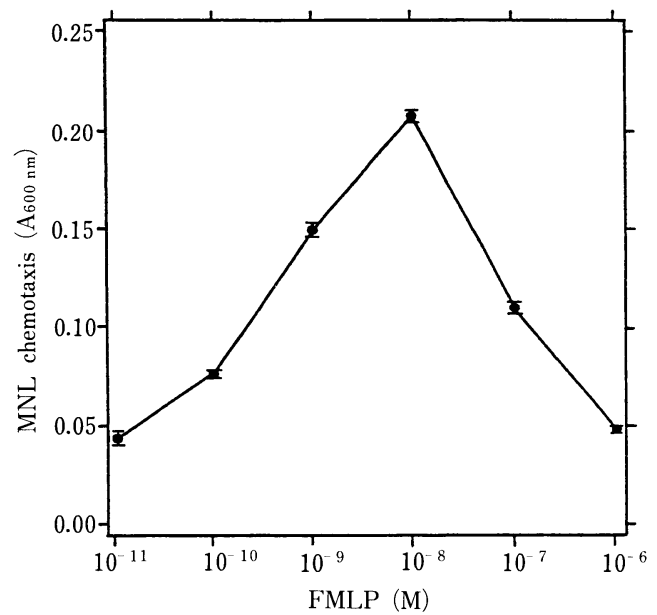

図 3 Dose dependent monocyte chemotaxis to FMLP

The indicated concentrations of FMLP were tested for monocyte chemotaxis. Data represents the mean $\pm \mathrm{SE}$ of triplicate filters (A $600 \mathrm{~nm}$, buffer control: $0.052 \pm 0.003)$.

\section{考 察}

in vitro での白血球の走化性試験 は, 研究室で の細胞機能の研究や白血球機能に異常のある疾患 の臨床検査の項目の一つとして広く行われてい る。走化性を評価するためには，細胞の形態を観 察して遊走方向を類推したり，一定時間内にもっ とも長い距離を遊走した細胞の移動距離や，一定 の距離を移動した遊走細胞の数を計測する必要が ある1 6). いずれの方法で測定するにしても，顕 微鏡下で多数の細胞について個々の形態を観察し たり，細胞を染色したあとメンブランフィルター を透明化したり，メンブランフィルター上のそれ ぞれの細胞遊走面について多数の視野の細胞数を 計測するなどの手順と操作は煩雑である.

本実験では96穴ケモタキシスチャンバーを用い てヒト単球の走化性試験を行い, 安定した正確な 定量的データを得ただけでなく，マイクロプレー トリーダーを用いて 1 度に 1 チャンバー(96 well) 単位の吸光度を測定することにより，短時間に大 量のサンプルの走化性を評価をすることができ た. ヒト単球の FMLP に対する走化性は $10^{-8} \mathrm{M}$ をピークとした用量反応曲線を示し(図 3 ), 光学 顕微鏡下で肉眼的に遊走細胞数を計測したデータ と同じ結果が得られた ${ }^{10)}$.

また，細胞浮遊液中の単球の密度を $1 \times 10^{6}$ 個/
表 1 Monocyte chemotaxis measured by the absorbance at various kinds of wavelength

\begin{tabular}{c|c}
\hline $\begin{array}{c}\text { wavelength } \\
\text { (nm) }\end{array}$ & absorbance* \\
\hline 450 & $0.090 \pm 0.004$ \\
492 & $0.165 \pm 0.009$ \\
550 & $0.210 \pm 0.016$ \\
600 & $0.210 \pm 0.013$ \\
700 & $0.165 \pm 0.012$ \\
\hline
\end{tabular}

* Human monocytes $\left(5 \times 10^{6}\right.$ cells $\mathrm{ml}$ ) were tested for chemotaxis to FMLP $\left(10^{-8} \mathrm{M}\right)$.

$\mathrm{ml}$ から $5 \times 10^{6}$ 個 $/ \mathrm{ml}$ の範囲で変化させたとこ ろ, 細胞密度が増加するのに伴って吸光度が直線 的に増加した(図 2 )。すなおち吸光度の増加は, フィルター下面まで遊走した細胞数が直線的に増 加したことをあらわした。

さらにマイクロプレートリーダーの波長を 450 $\mathrm{nm}$ から $700 \mathrm{~nm}$ の範囲で変化させて測定したと ころ，波長 $550 \mathrm{~nm}$ と $600 \mathrm{~nm}$ でもっとも高い吸 光度を示した（表 1 ）。 らなみに $492 \mathrm{~nm}$ 打よび $700 \mathrm{~nm}$ でそれぞれ測定した場合にはわずかに感 度が低下するものの, 走化性因子の濃度および遊 走細胞数に対する用量反応性は $550 \mathrm{~nm}$ と 600 $\mathrm{nm}$ で測定した場合と同じ傾向を示した(data not shown). 走化性因子の濃度および遊走細胞数に対 するこのような用量反応性は，それぞれ 3 回以上 繰り返し行った実験で明膫に再現し，96穴ヶモタ キシスチャンバーとマイクロプレートリーダーを 用いた試験で得られた結果が信頼できることを示 した。

遊走細胞数を肉眼的に計測する方法と比較し て, 細胞の走化性を吸光度で測定することにより 客観的なデータが得られるだけでなく，短時間に 多くの検体の評価を行らことが可能となる。 ま た，96穴ケモタキシスチャンバーは，従来の48穴 チャンバーにくらべて処理できる検体数がたんに 2 倍となるだけでなく，well の配置が市販の96穴 組織培養プレートと同一であるため, マルチチャ ンネルピペットを用いて走化性因子および細胞浮 遊液を各 well に充填することができる.さらに， 金属性のフレームがついたメンブランフィルター （図 1 ）は取り扱いがきわめて便利であることなど は, 操作時間をより一層短縮するのに役立つ。 


\section{文 献}

1) McCutcheon, M., Wartman, W.B., Dixon, H.M.: Chemotropism of leukocytes in vitro; attraction by dried leukocytes, paraffin, glass and Staphylococcus albus. Arch. Pahol. 17: 607614, 1934.

2) Ketchel, M.M., Favour, C.B.: The acceleration and inhibition of migration of human leucocytes in vitro by plasma protein fractions. J. Exp. Med. 101: 647-663, 1955.

3) Cutler, J.E.: A simple in vitro method for studies on chemotaxis. Proc. Soc. Exp. Biol. Med. 147: 471-474, 1974.

4) Boyden, S.: The chemotactic effect of mixtures of antibody and antigen on polymorphonuclear leucocytes. J. Exp. Med. 115: 453-466, 1962.

5) Falk, W., Goodwin, Jr, R.H., Leonard, E.J.: A 48-well micro chemotaxis assembly for rapid and accurate measurement of leukocyte migration. J. Immunol. Methods 33: 239-247, 1980.

6) Harvath, L., Falk, W., Leonard, E.J.: Rapid quantitation of neutrophil chemotaxis. Use of a polyvinylpyrrolidone-free polycarbonate membrane in a multiwell assembly. J. Immunol. Methods 37: 39-45, 1980.

7) Tsukamoto, Y., Fukuda, K., Ishikawa, M., Ieiri, M., Uwazumi, K., Mori, M.: In vitro effect of histamine on monocyte chemotaxis. Jpn. J. Oral Biol. 24: 523-524, 1982.

8）塚本芳雄, 福田訓子, 森川 裕, 藤本平藏, 森 政和, 梅本俊夫 : 齿周病関連細菌之白血球遊走. 炎症 4：635-637, 1984.

9) Böyum, A.: Isolation of mononuclear cells and granulocytes from human blood. Isolation of mononuclear cells by one centrifugation, and of granulocytes by combining centrifugation and sedimentation at $1 \mathrm{~g}$. Scand. J. Clin. Lab. Invest. 97(suppl.): 77-89, 1968.

10）塚本芳雄：自律神経作働性薬の Monocyte 遊走に

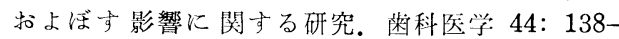
154, 1981. 